Aim of the study: To analyze the 100 most cited lung cancer articles published in biomedical literature in the last 44 years. We pointed out developments in lung cancer and aimed to create convenient access for the researchers of this dynamic field.

Material and methods: We accessed the WoS database (accessed: 15.07.2019) using the keyword "lung cancer" between 1975 and 2019. The top 100 cited articles were analyzed by topic, journal, author, year, institution, level of evidence, adjusted citation index and also the correlations between citation, adjusted citation index, impact factor and length of time since publication.

Results: A total of 240,701 eligible articles were identified and we chose the top 100 articles cited in the field of lung cancer. The mean number of citations for these articles was 1879.82 \pm 1264.78 . The most cited article was (times cited: 7751) a study by Lynch et al. The New England Journal of Medicine (NEJM) made the greatest contribution to the top 100 list with 32 articles, and the most cited article also originated from NEJM. The highest number of citations was seen in 2017 with 18,393 citations while the highest number of publications was seen in 2005 with 12 publications.

Conclusions: Oncology is a developing field and we have seen the evolution in this area through the treatment of lung cancer in recent years. The first 100 articles in our analysis not only reflect the landmark articles with the greatest impact on lung cancer research, but also acknowledge the most productive authors and institutions that have contributed to the list with their articles.

Key words: bibliometric study, citation, lung cancer.

Contemp Oncol (Pozn) 2019; 24 (1): 17-28 DOI: https://doi.org/10.5114/wo.2020.94725

\section{The top 100 cited articles in lung cancer - a bibliometric analysis}

\author{
Nilay Sengul Samanci, Emir Celik
}

Department of Medical Oncology, Istanbul University-Cerrahpasa, Cerrahpasa Medical Faculty, Istanbul, Turkey

\section{Introduction}

Lung cancer is an important health problem with an increasing incidence. In most European countries, lung cancer has increased so dramatically that it may be considered one of the major health problems in the last century [1]. The most common causes of cancer-related death are cancers of the lung and bronchus (24\%), prostate (10\%) and colorectum (9\%) in men, and lung and bronchus (23\%), breast (15\%), and colorectum (8\%) in women [2]. Although lung cancer has long been characterized by late-stage diagnosis and poor survival, encouraging results have been achieved for lung cancer screening in high-risk populations in the last decade and there has been significant progress in systemic treatments for molecular subgroups of patients with advanced disease. Furthermore, within the last ten years, new molecular targets have emerged, next-generation drugs with more specific target effects have been introduced, and targeting specific resistant mutations is expected to advance the treatment of lung cancer by creating a chronic therapeutic pathway [3]. This bibliometric study demonstrates the development of lung cancer treatment over the years.

Bibliometric studies represent an important study type showing the trend topics in a given field. Numerous medical and surgical specialists have published the most cited articles in their specialties in the form of bibliometric analysis such as general surgery [4], anesthesiology [5], orthopedics [6], otolaryngology [7], radiology [8] and plastic surgery [9]. The first bibliometric analysis was penned by Garfield and published in JAMA in 1987 [10]. He also continued with new bibliometric studies in different fields of medical science.

The purpose of our study was to identify and analyze the 100 most cited lung cancer articles published in biomedical literature in the last 44 years. We determined the number of citations with ranking, average citations per year (ACY), citations and publications by year, publishing journal, institution and country of origin, the most common subject of frequently cited articles, authorship status of classical papers and correlation analyses between citation, ACY, Impact Factor (IF) and length of time since publication in years.

\section{Material and methods}

\section{Study design}

Study type: retrospective clinical study, Level of evidence: 3 or Group B (Scottish Intercollegiate Guidelines Network; SIGN) [11].

Data collection and inclusion criteria: In this paper reporting a bibliometric citation analysis, data were obtained from Thomson Reuters' WoS Core Collection database (Philadelphia, Pennsylvania, USA) and PubMed (US National Library of Medicine-National Institutes of Health). We accessed the WoS database (accessed: 15.07.2019) using the keyword "lung cancer" between 1975 and 2019. We identified 240,701 articles and conducted an analysis of the top 100 cited articles among these hits shown in Table 1 [12-111]. Articles not relevant to lung cancer were excluded from our study and we included original re- 
Table 1 . The top 100 cited articles in lung cancer

\begin{tabular}{|c|c|c|c|}
\hline Rank & Article & Citations & $\mathrm{ACY}^{*}$ \\
\hline 1 & $\begin{array}{l}\text { Lynch TJ, Bell D, Sordella R, et al. Activating mutations in the epidermal growth factor receptor underlying } \\
\text { responsiveness of nonsmallcell lung cancer to gefitinib. N Engl J Med 2004; 350: 2129-2139 }\end{array}$ & 7751 & 484.44 \\
\hline 2 & $\begin{array}{l}\text { Aaronson NK, Ahmedzai S, Bergman B, et al. The European Organization for Research and Treatment } \\
\text { of Cancer QLQC30: a quality-of-life instrument for use in international clinical trials in oncology. J Natl } \\
\text { Cancer Inst 1993; 85: 365-376 }\end{array}$ & 7190 & 266.30 \\
\hline 3 & $\begin{array}{l}\text { Paez JG, Jänne PA, Lee JC, et al. EGFR mutations in lung cancer: correlation with clinical response to } \\
\text { gefitinib therapy. Science 2004; 304: 1497-1500 }\end{array}$ & 6599 & 412.44 \\
\hline 4 & $\begin{array}{l}\text { Mok TS, Wu YL, Thongprasert S, et al. Gefitinib or carboplatin-paclitaxel in pulmonary adenocarcinoma. } \\
\text { N Engl J Med 2009; 361: 947-957 }\end{array}$ & 4907 & 446.09 \\
\hline 5 & $\begin{array}{l}\text { Shepherd FA, Rodrigues Pereira J, Ciuleanu T, et al. Erlotinib in previously treated nonsmallcell lung } \\
\text { cancer. N Engl J Med 2005; 353: 123-132 }\end{array}$ & 4163 & 277.53 \\
\hline 6 & $\begin{array}{l}\text { Sandler A, Gray R, Perry MC, et al. Paclitaxel-carboplatin alone or with bevacizumab for non-small-cell } \\
\text { lung cancer. N Engl J Med 2006; 355: 2542-2550 }\end{array}$ & 4076 & 291.14 \\
\hline 7 & $\begin{array}{l}\text { Schiller JH, Harrington D, Belani CP, et al. Comparison of four chemotherapy regimens for advanced non- } \\
\text { small-cell lung cancer. N Engl J Med 2002; 346: 92-98 }\end{array}$ & 3672 & 204 \\
\hline 8 & Mountain CF. Revisions in the International System for Staging Lung Cancer. Chest 1997; 111: 1710-1717 & 3663 & 159.26 \\
\hline 9 & $\begin{array}{l}\text { National Lung Screening Trial Research Team, Aberle DR, Adams AM, et al. Reduced lung-cancer mortality } \\
\text { with lowdose computed tomographic screening. N Engl J Med 2011; 365: 395-409 }\end{array}$ & 3539 & 393.22 \\
\hline 10 & $\begin{array}{l}\text { Maemondo M, Inoue A, Kobayashi K, et al. Gefitinib or chemotherapy for non-small-cell lung cancer with } \\
\text { mutated EGFR. N Engl J Med. 2010; 362: 2380-2388 }\end{array}$ & 3077 & 307.7 \\
\hline 11 & $\begin{array}{l}\text { Temel JS, Greer JA, Muzikansky A, et al. Early palliative care for patients with metastatic non-small-cell } \\
\text { lung cancer. N Engl J Med 2010; 363: 733-742 }\end{array}$ & 3042 & 304.2 \\
\hline 12 & $\begin{array}{l}\text { Engelman JA, Zejnullahu K, Mitsudomi T, et al. MET amplification leads to gefitinib resistance in lung } \\
\text { cancer by activating ERBB3 signaling. Science 2007; 316: 1039-1043 }\end{array}$ & 3000 & 230.77 \\
\hline 13 & $\begin{array}{l}\text { Brahmer J, Reckamp KL, Baas P, et al. Nivolumab versus Docetaxel in Advanced Squamous-Cell Non- } \\
\text { Small-Cell Lung Cancer. N Engl J Med 2015; 373: 123-135 }\end{array}$ & 2966 & 593.2 \\
\hline 14 & $\begin{array}{l}\text { Soda M, Choi YL, Enomoto M, et al. Identification of the transforming EML4-ALK fusion gene in non- } \\
\text { small-cell lung cancer. Nature 2007; 448: 561-566 }\end{array}$ & 2960 & 227.69 \\
\hline 15 & $\begin{array}{l}\text { Kwak EL, Bang YJ, Camidge DR, et al. Anaplastic lymphoma kinase inhibition in non-small-cell lung cancer. } \\
\text { N Engl J Med 2010; 363: 1693-1703 }\end{array}$ & 2910 & 291 \\
\hline 16 & $\begin{array}{l}\text { Borghaei H, Paz-Ares L, Horn L, et al. Nivolumab versus Docetaxel in Advanced Nonsquamous Non-Small- } \\
\text { Cell Lung Cancer. Engl J Med 2015; 373: 1627-1639 }\end{array}$ & 2907 & 581.40 \\
\hline 17 & $\begin{array}{l}\text { Rosell R, Carcereny E, Gervais R, et al. Erlotinib versus standard chemotherapy as first-line treatment } \\
\text { for European patients with advanced EGFR mutation-positive non-small-cell lung cancer (EURTAC): } \\
\text { a multicentre, open-label, randomised phase } 3 \text { trial. Lancet Oncol 2012; 13: 239-246 }\end{array}$ & 2804 & 350.5 \\
\hline 18 & $\begin{array}{l}\text { Cole SP, Bhardwaj G, Gerlach JH, et al. Overexpression of a transporter gene in a multidrug-resistant } \\
\text { human lung cancer cell line. Science 1992; 258: 1650-1654 }\end{array}$ & 2786 & 99.50 \\
\hline 19 & $\begin{array}{l}\text { Kobayashi S, Boggon TJ, Dayaram T, et al. EGFR mutation and resistance of non-small-cell lung cancer } \\
\text { to gefitinib. N Engl J Med 2005; 352: 786-792 }\end{array}$ & 2549 & 169.93 \\
\hline 20 & $\begin{array}{l}\text { Rizvi NA, Hellmann MD, Snyder A, et al. Cancer immunology. Mutational landscape determines sensitivity } \\
\text { to PD-1 blockade in non-small cell lung cancer. Science 2015; 348: 124-128 }\end{array}$ & 2501 & 500.2 \\
\hline 21 & $\begin{array}{l}\text { Non-small Cell Lung Cancer Collaborative Group. Chemotherapy in non-small cell lung cancer: a meta- } \\
\text { analysis using updated data on individual patients from } 52 \text { randomised clinical trials. BMJ 1995; 311: } \\
\text { 899-909 }\end{array}$ & 2474 & 98.96 \\
\hline 22 & $\begin{array}{l}\text { Mitsudomi T, Morita S, Yatabe Y, et al. Gefitinib versus cisplatin plus docetaxel in patients with non-small- } \\
\text { cell lung cancer harbouring mutations of the epidermal growth factor receptor (WJTOG3405): an open } \\
\text { label, randomised phase } 3 \text { trial. Lancet Oncol 2010; 11: 121-128. }\end{array}$ & 2447 & 244.7 \\
\hline 23 & $\begin{array}{l}\text { Travis WD, Brambilla E, Noguchi M, et al. International association for the study of lung cancer/american } \\
\text { thoracic society/european respiratory society international multidisciplinary classification of lung } \\
\text { adenocarcinoma. J Thorac Oncol 2011; 6: } 244-285\end{array}$ & 2309 & 256.6 \\
\hline 24 & $\begin{array}{l}\text { Fukuoka M, Yano S, Giaccone G, et al. Multi-institutional randomized phase II trial of gefitinib for } \\
\text { previously treated patients with advanced non-small-cell lung cancer (The IDEAL } 1 \text { Trial). J Clin Oncol } \\
\text { 2003; 21: 2237-2246 }\end{array}$ & 2256 & 132.71 \\
\hline 25 & $\begin{array}{l}\text { Zhou C, Wu YL, Chen G, et al. Erlotinib versus chemotherapy as firstline treatment for patients with } \\
\text { advanced EGFR mutation-positive non-small-cell lung cancer (OPTIMAL, CTONG0802): a multicentre, } \\
\text { open-label, randomised, phase } 3 \text { study. Lancet Oncol 2011; 12: 735-742 }\end{array}$ & 2227 & 247.44 \\
\hline
\end{tabular}


Table 1. Cont.

\begin{tabular}{|c|c|c|c|}
\hline 26 & $\begin{array}{l}\text { Yanaihara N, Caplen N, Bowman E, et al. Unique microRNA molecular profiles in lung cancer diagnosis } \\
\text { and prognosis. Cancer Cell 2006; 9: 189-198 }\end{array}$ & 2201 & 157.21 \\
\hline 27 & $\begin{array}{l}\text { Goldstraw P, Crowley J, Chansky K, et al. The IASLC Lung Cancer Staging Project: proposals for the revision } \\
\text { of the TNM stage groupings in the forthcoming (seventh) edition of the TNM Classification of malignant } \\
\text { tumours. J Thorac Oncol 2007; 2: 706-714 }\end{array}$ & 2185 & 168.08 \\
\hline 28 & $\begin{array}{l}\text { Garon EB, Rizvi NA, Hui R, et al. Pembrolizumab for the treatment of non-small-cell lung cancer. N Engl } \\
\text { J Med 2015; 372: 2018-2028 }\end{array}$ & 2127 & 425.4 \\
\hline 29 & $\begin{array}{l}\text { Scagliotti GV, Parikh P, von Pawel J, et al. Phase III study comparing cisplatin plus gemcitabine with } \\
\text { cisplatin plus pemetrexed in chemotherapy-naive patients with advanced-stage non-small-cell lung } \\
\text { cancer. J Clin Oncol 2008; 26: 3543-3551 }\end{array}$ & 2108 & 175.67 \\
\hline 30 & $\begin{array}{l}\text { Pao W, Miller VA, Politi KA, et al. Acquired resistance of lung adenocarcinomas to gefitinib or erlotinib is } \\
\text { associated with a second mutation in the EGFR kinase domain. PLoS Med 2005; 2: e73 }\end{array}$ & 2073 & 138.2 \\
\hline 31 & $\begin{array}{l}\text { Kris MG, Natale RB, Herbst RS, et al. Efficacy of gefitinib, an inhibitor of the epidermal growth factor } \\
\text { receptor tyrosine kinase, in symptomatic patients with non-small cell lung cancer: a randomized trial. } \\
\text { JAMA 2003; 290: 2149-2158 }\end{array}$ & 1998 & 117.53 \\
\hline 32 & $\begin{array}{l}\text { Reck M, Rodríguez-Abreu D, Robinson AG, et al. Pembrolizumab versus Chemotherapy for PD-L1-Positive } \\
\text { Non-Small-Cell Lung Cancer. N Engl J Med 2016; 375: 1823-1833 }\end{array}$ & 1970 & 492.5 \\
\hline 33 & $\begin{array}{l}\text { Shaw AT, Kim DW, Nakagawa K, et al. Crizotinib versus chemotherapy in advanced ALK-positive lung } \\
\text { cancer. N Engl J Med 2013; 368: 2385-2394 }\end{array}$ & 1906 & 272.29 \\
\hline 34 & $\begin{array}{l}\text { Cancer Genome Atlas Research Network. Comprehensive genomic characterization of squamous cell } \\
\text { lung cancers. Nature 2012; 489: 519-525 }\end{array}$ & 1806 & 225.75 \\
\hline 35 & $\begin{array}{l}\text { Hanna N, Shepherd FA, Fossella FV, et al. Randomized phase III trial of pemetrexed versus docetaxel in } \\
\text { patients with non-small-cell lung cancer previously treated with chemotherapy. J Clin Oncol 2004; 22: } \\
\text { 1589-1597 }\end{array}$ & 1773 & 110.81 \\
\hline 36 & $\begin{array}{l}\text { Takamizawa J, Konishi H, Yanagisawa K, et al. Reduced expression of the let-7 microRNAs in human lung } \\
\text { cancers in association with shortened postoperative survival. Cancer Res 2004; 64: 3753-3756 }\end{array}$ & 1729 & 108.06 \\
\hline 37 & $\begin{array}{l}\text { Sharma SV, Bell DW, Settleman J, Haber DA. Epidermal growth factor receptor mutations in lung cancer. } \\
\text { Nat Rev Cancer 2007; 7: 169-181 }\end{array}$ & 1722 & 132.46 \\
\hline 38 & $\begin{array}{l}\text { Herbst RS, Baas P, Kim DW, et al. Pembrolizumab versus docetaxel for previously treated, PD-L1- positive, } \\
\text { advanced non-small-cell lung cancer (KEYNOTE-010): a randomised controlled trial. Lancet 2016; 387: } \\
\text { 1540-1550 }\end{array}$ & 1705 & 426.5 \\
\hline 39 & $\begin{array}{l}\text { Henschke CI, McCauley DI, Yankelevitz DF, et al. Early Lung Cancer Action Project: overall design and } \\
\text { findings from baseline screening. Lancet 1999; 354: 99-105 }\end{array}$ & 1665 & 79.29 \\
\hline 40 & $\begin{array}{l}\text { Bhattacharjee A, Richards WG, Staunton J, et al. Classification of human lung carcinomas by mRNA } \\
\text { expression profiling reveals distinct adenocarcinoma subclasses. Proc Natl Acad Sci U S A 2001; } 98 \text { : } \\
\text { 13790-13795 }\end{array}$ & 1645 & 86.58 \\
\hline 41 & $\begin{array}{l}\text { Sequist LV, Waltman BA, Dias-Santagata D, et al. Genotypic and histological evolution of lung cancers } \\
\text { acquiring resistance to EGFR inhibitors. Sci Transl Med 2011; 3: 75ra26 }\end{array}$ & 1636 & 181.78 \\
\hline 42 & $\begin{array}{l}\text { Thatcher N, Chang A, Parikh P, et al. Gefitinib plus best supportive care in previously treated patients } \\
\text { with refractory advanced non-small-cell lung cancer: results from a randomised, placebo-controlled, } \\
\text { multicentre study (Iressa Survival Evaluation in Lung Cancer). Lancet 2005; 366: 1527-1537 }\end{array}$ & 1628 & 108.53 \\
\hline 43 & $\begin{array}{l}\text { Shigematsu H, Lin L, Takahashi T, et al. Clinical and biological features associated with epidermal growth } \\
\text { factor receptor gene mutations in lung cancers. I Natl Cancer Inst 2005; 97: 339-346 }\end{array}$ & 1607 & 107.13 \\
\hline 44 & $\begin{array}{l}\text { Shepherd FA, Dancey J, Ramlau R, et al. Prospective randomized trial of docetaxel versus best supportive } \\
\text { care in patients with non-small-cell lung cancer previously treated with platinum-based chemotherapy. } \\
\text { J Clin Oncol 2000; 18: 2095-2103 }\end{array}$ & 1551 & 77.55 \\
\hline 45 & $\begin{array}{l}\text { Murren JR, Buzaid AC, Hait WN. Critical analysis of neoadjuvant therapy for Stage Illa non-small cell lung } \\
\text { cancer. Am Rev Respir Dis 1991; 143: 889-894. }\end{array}$ & 1509 & 52.03 \\
\hline 46 & Mountain CF. A new international staging system for lung cancer. Chest 1986; 89: 225S-233S & 1509 & 44.38 \\
\hline 47 & $\begin{array}{l}\text { Rosell R, Moran T, Queralt C, et al. Screening for epidermal growth factor receptor mutations in lung } \\
\text { cancer. N Engl J Med 2009; 361: 958-967 }\end{array}$ & 1483 & 34.82 \\
\hline 48 & $\begin{array}{l}\text { Arriagada R, Bergman B, Dunant A, Le Chevalier T, Pignon JP, Vansteenkiste J; International Adjuvant Lung } \\
\text { Cancer Trial Collaborative Group. Cisplatin-based adjuvant chemotherapy in patients with completely } \\
\text { resected non-small-cell lung cancer. N Engl J Med 2004; 350: 351-360 }\end{array}$ & 1471 & 91.94 \\
\hline 49 & Herbst RS, Heymach JV, Lippman SM. Lung cancer. N Engl J Med 2008; 359: 1367-1380 & 1451 & 120.92 \\
\hline 50 & $\begin{array}{l}\text { Rikova K, Guo A, Zeng Q, et al. Global survey of phosphotyrosine signaling identifies oncogenic kinases in } \\
\text { lung cancer. Cell 2007; 131: 1190-1203 }\end{array}$ & 1436 & 110.46 \\
\hline
\end{tabular}


Table 1. Cont.

51 Johnson DH, Fehrenbacher L, Novotny WF, et al. Randomized phase II trial comparing bevacizumab plus carboplatin and paclitaxel with carboplatin and paclitaxel alone in previously untreated locally advanced or metastatic non-small-cell lung cancer. J Clin Oncol 2004; 22: 2184-2191

52 Tsao MS, Sakurada A, Cutz JC, et al. Erlotinib in lung cancer - molecular and clinical predictors of outcome. N Engl J Med 2005; 353: 133-144

53 Kim CF, Jackson EL, Woolfenden AE, et al. Identification of bronchioalveolar stem cells in normal lung and lung cancer. Cell 2005; 121: 823-835

54 Timmerman R, Paulus R, Galvin J, et al. Stereotactic body radiation therapy for inoperable early stage lung cancer. JAMA 2010; 303: 1070-1076

55 Giaccone G, Herbst RS, Manegold C, et al. Gefitinib in combination with gemcitabine and cisplatin in advanced non-small-cell lung cancer: a phase III trial - INTACT 1. J Clin Oncol 2004; 22: 777-784

56 Herbst RS, Giaccone G, Schiller JH, et al. Gefitinib in combination with paclitaxel and carboplatin in advanced non-small-cell lung cancer: a phase III trial - INTACT 2. J Clin Oncol 2004; 22: 785-794

Solomon BJ, Mok T, Kim DW, et al. First-line crizotinib versus chemotherapy in ALK-positive lung cancer. N Engl J Med 2014; 371: 2167-2177

58 Denissenko MF, Pao A, Tang M, Pfeifer GP. Preferential formation of benzo[a]pyrene adducts at lung cancer mutational hotspots in P53. Science 1996; 274: 430-432

59 Olaussen KA, Dunant A, Fouret P, et al. DNA repair by ERCC1 in non-small-cell lung cancer and cisplatinbased adjuvant chemotherapy. N Engl J Med 2006; 355: 983-991

60 Hecht SS. Tobacco smoke carcinogens and lung cancer. J Natl Cancer Inst 1999; 91: 1194-1210 128

61 Molina JR, Yang P, Cassivi SD, Schild SE, Adjei AA. Non-small cell lung cancer: epidemiology, risk factors, 1280 treatment, and survivorship. Mayo Clin Proc 2008; 83: 584-594

62 Cuttitta F, Carney DN, Mulshine J, et al. Bombesin-like peptides can function as autocrine growth factors 1280 in human small-cell lung cancer. Nature 1985; 316: 823-826

63 Cappuzzo F, Hirsch FR, Rossi E, et al. Epidermal growth factor receptor gene and protein and gefitinib sensitivity in non-small-cell lung cancer. J Natl Cancer Inst 2005; 97: 643-655

64 Sordella R, Bell DW, Haber DA, Settleman J. Gefitinib-sensitizing EGFR mutations in lung cancer activate antiapoptotic pathways. Science 2004; 305: 1163-1167

65 Winton T, Livingston R, Johnson D, et al. Vinorelbine plus cisplatin vs. observation in resected non-smallcell lung cancer. N Engl J Med 2005; 352: 2589-2597

66 Takahashi T, Nau MM, Chiba I, et al. p53: a frequent target for genetic abnormalities in lung cancer. Science 1989; 246: 491-494

67 Maheswaran S, Sequist LV, Nagrath S, et al. Detection of mutations in EGFR in circulating lung-cancer cells. N Engl J Med 2008; 359: 366-377

68 Iggo R, Gatter K, Bartek J, Lane D, Harris AL. Increased expression of mutant forms of p53 oncogene in primary lung cancer. Lancet 1990; 335: 675-679 and survival in early-stage non-small cell lung cancer. Oncogene 2003; 22: 8031-8041

70 Shaw AT, Yeap BY, Mino-Kenudson M, et al. Clinical features and outcome of patients with non-small-cell 1140 lung cancer who harbor EML4-ALK. J Clin Oncol 2009; 27: 4247-4253

71 Crawford J, Ozer H, Stoller R, et al. Reduction by granulocyte colony-stimulating factor of fever and neutropenia induced by chemotherapy in patients with small-cell lung cancer. N Engl J Med 1991; 325 : 164-170

72 Hayashita Y, Osada H, Tatematsu Y, et al. A polycistronic microRNA cluster, miR-17-92, is overexpressed in human lung cancers and enhances cell proliferation. Cancer Res 2005; 65: 9628-9632

73 Herbst RS, Prager D, Hermann R, et al. TRIBUTE: a phase III trial of erlotinib hydrochloride (OSI-774) combined with carboplatin and paclitaxel chemotherapy in advanced non-small-cell lung cancer. J Clin Oncol 2005; 23: 5892-5899

74 Eberhard DA, Johnson BE, Amler LC, et al. Mutations in the epidermal growth factor receptor and in KRAS are predictive and prognostic indicators in patients with non-small-cell lung cancer treated with chemotherapy alone and in combination with erlotinib. J Clin Oncol 2005; 23: 5900-5909

75 Eramo A, Lotti F, Sette G, et al. Identification and expansion of the tumorigenic lung cancer stem cell population. Cell Death Differ 2008; 15: 504-514

76 Fabbri M, Garzon R, Cimmino A, et al. MicroRNA-29 family reverts aberrant methylation in lung cancer by targeting DNA methyltransferases 3A and 3B. Proc Natl Acad Sci U S A 2007; 104: 15805-15810 
Table 1. Cont.

77 Yun CH, Mengwasser KE, Toms AV, et al. The T790M mutation in EGFR kinase causes drug resistance by increasing the affinity for ATP. Proc Natl Acad Sci U S A 2008; 105: 2070-2075

78 Schaake-Koning C, van den Bogaert W, Dalesio O, et al. Effects of concomitant cisplatin and radiotherapy 1047 on inoperable non-small-cell lung cancer. N Engl J Med 1992; 326: 524-530

79 Furuse K, Fukuoka M, Kawahara M, et al. Phase III study of concurrent versus sequential thoracic $1046 \quad 49.81$ radiotherapy in combination with mitomycin, vindesine, and cisplatin in unresectable stage III non-smallcell lung cancer. J Clin Oncol 1999; 17: 2692-2699

80 International Early Lung Cancer Action Program Investigators, Henschke Cl, Yankelevitz DF, Libby DM, et al. Survival of patients with stage I lung cancer detected on CT screening. N Engl J Med 2006; 355: 1763-1771.

81 Pignon JP, Tribodet H, Scagliotti GV, et al. Lung adjuvant cisplatin evaluation: a pooled analysis by the LACE Collaborative Group. J Clin Oncol 2008; 26: 3552-3559

82 Reck M, von Pawel J, Zatloukal P, et al. Phase III trial of cisplatin plus gemcitabine with either placebo or bevacizumab as first-line therapy for nonsquamous non-small-cell lung cancer: AVAil. J Clin Oncol 2009; 27: $1227-1234$

83 Jackson EL, Willis N, Mercer K, et al. Analysis of lung tumor initiation and progression using conditional expression of oncogenic K-ras. Genes Dev 2001; 15: 3243-3248

84 Pirker R, Pereira JR, Szczesna A, et al. Cetuximab plus chemotherapy in patients with advanced nonsmall- 1002 cell lung cancer (FLEX): an open-label randomised phase III trial. Lancet 2009; 373: 1525-1531

85 Kim ES, Hirsh V, Mok T, et al. Gefitinib versus docetaxel in previously treated non-small-cell lung cancer (INTEREST): a randomised phase III trial. Lancet 2008; 372: 1809-1818

86 Govindan R, Page N, Morgensztern D, et al. Changing epidemiology of small-cell lung cancer in the United States over the last 30 years: analysis of the surveillance, epidemiologic, and end results database. J Clin Oncol 2006; 24: 4539-4544

87 Jänne PA, Yang JC, Kim DW, et al. AZD9291 in EGFR inhibitor-resistant non-small-cell lung cancer. N Eng J Med 2015; 372: 1689-1699

88 Fossella FV, DeVore R, Kerr RN, et al. Randomized phase III trial of docetaxel versus vinorelbine or ifosfamide in patients with advanced non-small-cell lung cancer previously treated with platinumcontaining chemotherapy regimens. The TAX 320 Non-Small Cell Lung Cancer Study Group. J Clin Oncol 2000; 18: 2354-2362

89 Pfister DG, Johnson DH, Azzoli CG, et al. American Society of Clinical Oncology treatment of unresectable non-small-cell lung cancer guideline: update 2003. J Clin Oncol 2004; 22: 330-353

90 Lardinois D, Weder W, Hany TF, et al. Staging of non-small-cell lung cancer with integrated positronemission tomography and computed tomography. N Engl J Med 2003; 348: 2500-2507

91 Dillman RO, Seagren SL, Propert KJ, et al. A randomized trial of induction chemotherapy plus high-dose radiation versus radiation alone in stage III non-small-cell lung cancer. N Engl J Med 1990; 323: $940-945$

92 Mountain CF, Dresler CM. Regional lymph node classification for lung cancer staging. Chest 1997; 111: 1718-1723

93 Aupérin A, Arriagada R, Pignon JP, et al. Prophylactic cranial irradiation for patients with small-cell lung cancer in complete remission. Prophylactic Cranial Irradiation Overview Collaborative Group. N Engl J Med 1999; 341: 476-484

94 Rosell R, Gómez-Codina J, Camps C, et al. A randomized trial comparing preoperative chemotherapy plus surgery with surgery alone in patients with non-small-cell lung cancer. N Engl J Med 1994; 330: 153-158

95 Rittmeyer A, Barlesi F, Waterkamp D, et al. Atezolizumab versus docetaxel in patients with previously treated non-small-cell lung cancer (OAK): a phase 3, open-label, multicentre randomised controlled trial. Lancet 2017; 389: 255-265

96 Douillard JY, Rosell R, De Lena M, et al. Adjuvant vinorelbine plus cisplatin versus observation in patients with completely resected stage IB-IIIA non-small-cell lung cancer (Adjuvant Navelbine International Trialist Association [ANITA]): a randomised controlled trial. Lancet Oncol 2006; 7: 719-727

97 Kosaka T, Yatabe Y, Endoh H, Kuwano H, Takahashi T, Mitsudomi T. Mutations of the epidermal growth factor receptor gene in lung cancer: biological and clinical implications. Cancer Res 2004; 64: 8919-8923

98 Cappuzzo F, Ciuleanu T, Stelmakh L, et al. Erlotinib as maintenance treatment in advanced non-small-cell lung cancer: a multicentre, randomised, placebo-controlled phase 3 study. Lancet Oncol 2010; 11: 521-529

99 Pignon JP, Arriagada R, Ihde DC, et al. A meta-analysis of thoracic radiotherapy for small-cell lung cancer. N Engl J Med 1992; 327: 1618-1624

100 Imielinski M, Berger AH, Hammerman PS, et al. Mapping the hallmarks of lung adenocarcinoma with massively parallel sequencing. Cell 2012; 150: 1107-1120 
Table 2. Type of treatment and level of evidence of the treatment based clinical articles $(n=59)$

\begin{tabular}{lcccc}
\hline Treatment & Level 1 & Level 2 & Level 3 & Level 4 \\
EGFR mutations & 17 & - & 6 & - \\
Chemotherapy & 19 & - & - & 1 \\
Palliative care & 1 & - & - & - \\
Immunotherapy & 5 & 1 & 1 & - \\
ALK mutations & 2 & - & 1 & - \\
Radiotherapy & 3 & 1 & 1 & - \\
EGFR - epidermal growth factor receptor, ALK - anaplastic lymphoma kinase
\end{tabular}

search articles, editorials, correspondences, review articles and case reports. We also utilized the PubMed database to obtain additional data related to the study. Two of the authors (NSS and EC) independently identified T100 with consensus. The difference in time since publication among the top 100 articles may cause a bias as older articles may be more likely to have obtained more citations owing to a longer citable period. The Web of Science, Citation Report feature displays bar charts for the number of items published each year and calculates the average number of citations per year per publication. Due to this bias, we used the ACY for each article.

\section{Statistical analysis}

A commercial software (SPSS version 16.0, SPSS, Chicago IL, USA) was used for the statistical analysis. The Kolmogorov-Smirnov test was used to analyze the normal distribution of data. Spearman's correlation was used to evaluate the associations between citation, ACY, IF and length of time since publication. A $p$-value $<0.05$ was accepted as statistically significant.

\section{Ethical statement}

All authors declare that the study was conducted according to the principles of the World Medical Association Declaration of Helsinki: Ethical Principles for Medical Research Involving Human Subjects. This study did not require approval from an ethics committee as it was designed as a bibliometric analysis or citation analysis of existing published classical studies.

\section{Results}

We identified 240,701 articles from 1975 to 2019. The language was English for all articles. The 100 most cited articles in lung cancer are listed in Table 1, arranged in descending order according to the number of times cited. The number of citations ranged from 7751 to 889 , and the mean number of citations per article was $1879.82 \pm 1264.78$ (range: 7751-889). We found that the most cited article (times cited: 7751) on lung cancer was a study by Lynch et al. with the following title: "Activating mutations in the epidermal growth factor receptor underlying responsiveness of nonsmallcell lung cancer to gefitinib" published in N Engl J Med 2004; 350: 2129-1239. The least cited article (times cited: 889) on lung cancer was penned by Imielinski et al. with the following title: "Mapping the hallmarks of
Table 3. List of journals with published articles

\begin{tabular}{|c|c|c|c|}
\hline Journal & $\begin{array}{l}\text { Number } \\
\text { of } \\
\text { articles }\end{array}$ & $\begin{array}{l}\text { Impact } \\
\text { Factor }\end{array}$ & $\begin{array}{l}\text { Quartile } \\
\text { score }^{* *}\end{array}$ \\
\hline $\begin{array}{l}\text { New England Journal of Medicine } \\
\text { (NEJM) }\end{array}$ & 32 & 79.258 & Q1 \\
\hline Journal of Clinical Oncology & 16 & 26.303 & Q1 \\
\hline Lancet & 7 & 53.254 & Q1 \\
\hline Science & 7 & 41.058 & Q1 \\
\hline Lancet Oncology & 5 & 36.418 & Q1 \\
\hline $\begin{array}{l}\text { Journal of the National Cancer } \\
\text { Institute (JNCI) }\end{array}$ & 4 & 11.238 & Q1 \\
\hline Cancer Research & 3 & 9.13 & Q1 \\
\hline Cell & 3 & 31.398 & Q1 \\
\hline Chest & 3 & 7.652 & Q1 \\
\hline Nature & 3 & 41.577 & Q1 \\
\hline $\begin{array}{l}\text { Proceedings of the National } \\
\text { Academy of Sciences of the United } \\
\text { States of America }\end{array}$ & 3 & 9.504 & Q1 \\
\hline $\begin{array}{l}\text { Journal of the American Medical } \\
\text { Association (JAMA) }\end{array}$ & 2 & 47.661 & Q1 \\
\hline Journal of Thoracic Oncology & 2 & 10.336 & Q1 \\
\hline $\begin{array}{l}\text { American Review of Respiratory } \\
\text { Disease }\end{array}$ & 1 & 6.27 & Q1 \\
\hline British Medical Journal (BMJ) & 1 & 2.12 & Q1 \\
\hline Cancer Cell & 1 & 22.844 & Q1 \\
\hline Cell Death \& Differentiation & 1 & 8.000 & Q1 \\
\hline Genes \& Development & 1 & 9.462 & Q1 \\
\hline Mayo Clinic Proceedings & 1 & 7.199 & Q1 \\
\hline Nature Reviews Cancer & 1 & 42.784 & Q1 \\
\hline Oncogene & 1 & 6.854 & Q1 \\
\hline PLOS Medicine & 1 & 11.675 & Q1 \\
\hline Science Translational Medicine & 1 & 16.710 & Q1 \\
\hline
\end{tabular}

"2017 Journal Citation Reports (Clarivate Analytics), " 2019 SCImago Journal and Country Rank

lung adenocarcinoma with massively parallel sequencing" and published in Cell 2012; 150: 1107-1120. Additionally, we determined that there were 84 articles that got more than 1000 citations and the article with the highest ACY was the article that ranked 16 in the T100 list. The article with the highest ACY was a randomized phase 3 trial by Borghaei et al., titled "Nivolumab versus docetaxel in advanced nonsquamous non-smallcell lung cancer" and published in N Engl J Med 2015; 373: 1627-1639. The highest number of citations was seen in 2017 with 18,393 citations while the highest number of publications was seen in 2005 with 12 publications.

The oldest article was a review published in Nature 1985; 316: 823-826 titled "Bombesin-like peptides can function as autocrine growth factors in human small-cell lung cancer" by Cuttitta et al. with 1280 citations and ACY 36.57 ACY. The newest study in the T100 list was a phase 3 trial conducted by Rittmeyer et al. published in Lancet 2017; 389: 255-265 with the following title: "Atezolizumab versus docetaxel in patients with previously treated non-small-cell lung cancer 
A
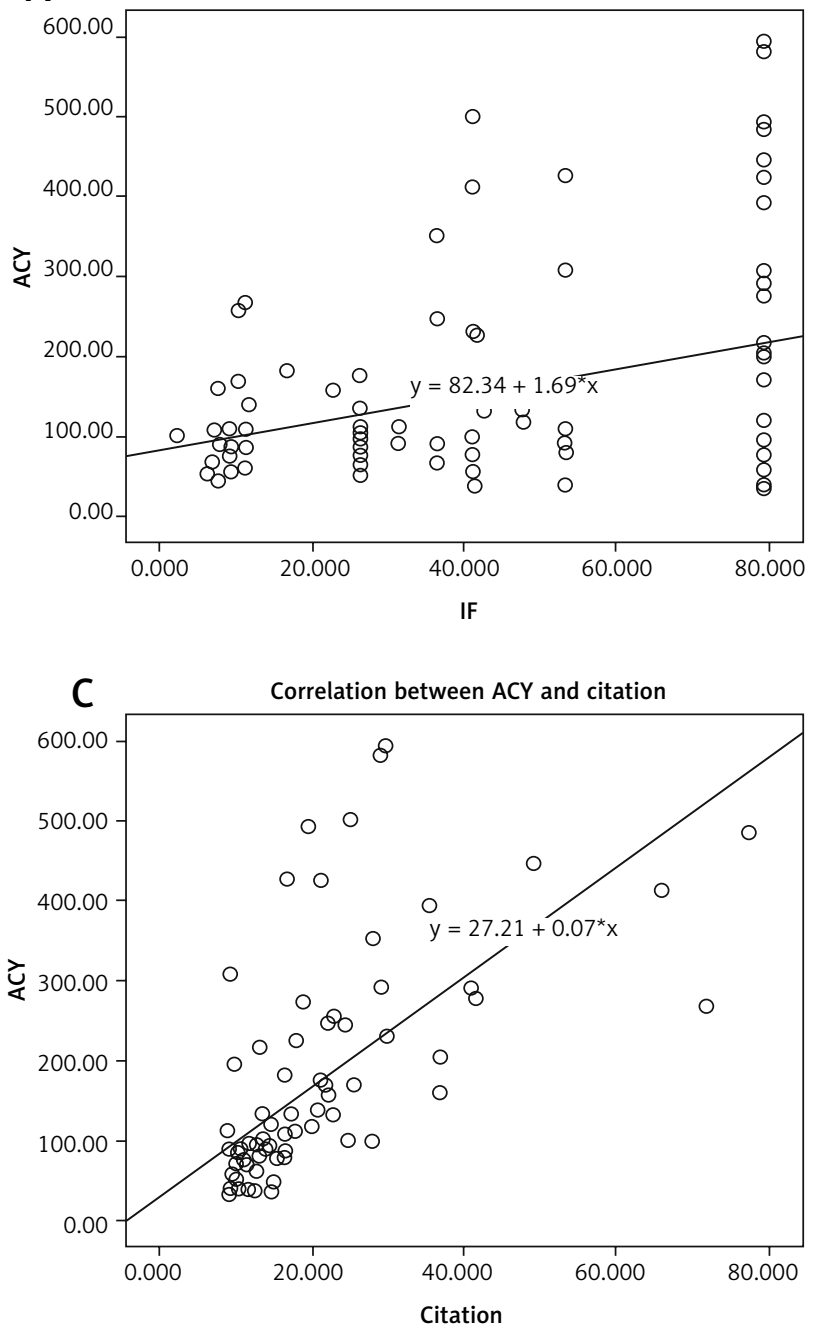

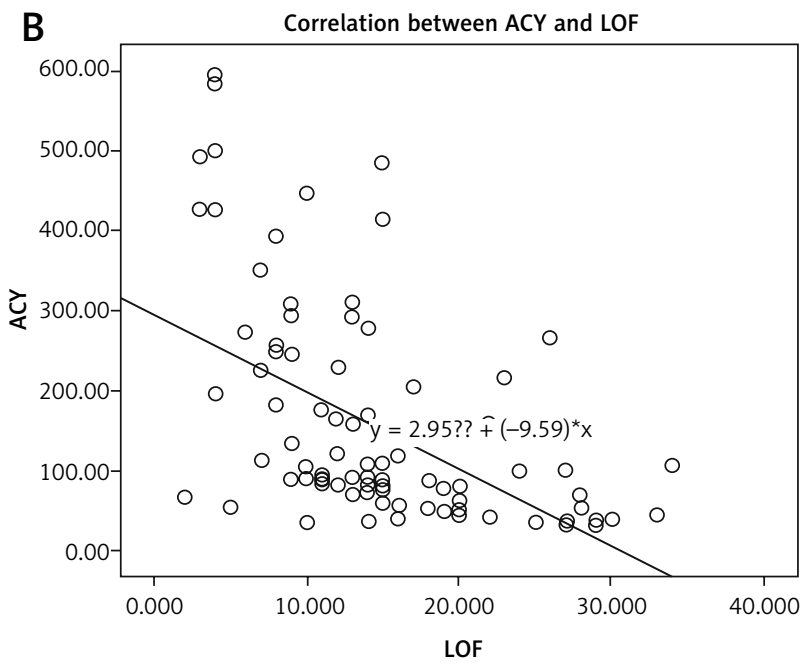

D Correlation between IF and LOF

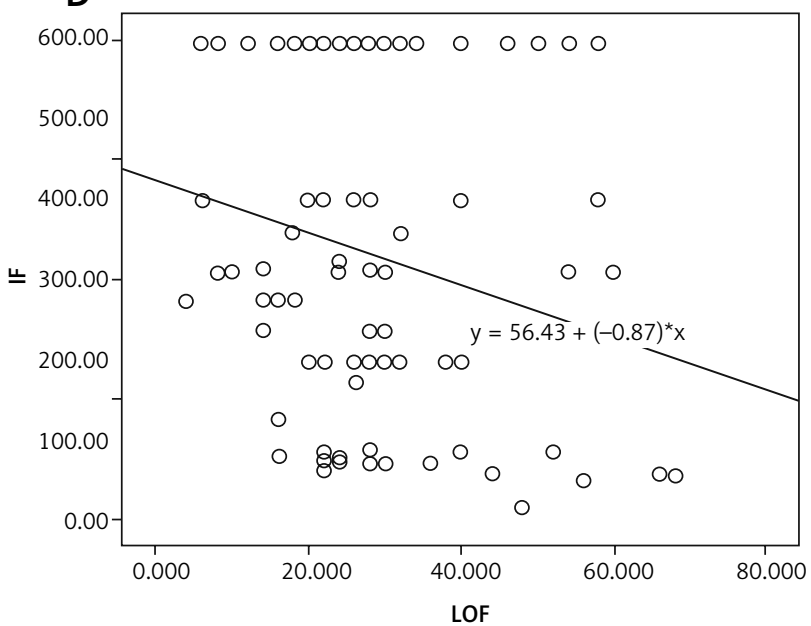

$A C Y$ - average citation per year, IF - impact factor, LOF - length of time since publication

Fig. 1. Correlation analysis for the citation numbers, ACY, IF, length of time since publication parameters

(OAK): a phase 3 , open-label, multicentre randomised controlled trial", with 926 citations and ACY 308.67.

In the T100 list, 82 were clinical studies and 18 were experimental studies. The 82 clinical articles included 42 randomized controlled studies, 8 review articles, 4 meta-analyses, 2 case reports and other clinical studies. Fifty-nine of these 82 clinical articles were treatment-based studies. The treatment-based studies are classified in Table 2 according to the level of evidence.

While 32 of these articles were published in NEJM, 16 were published in the Journal of Clinical Oncology, 7 in The Lancet, 7 in Science, etc. (Table 3).

All of the T100 articles were published across 23 different journals. Eighty-five of the T100 articles were published in 14 journals that had IF $\geq 10.336$. We determined that the mean IF of these 23 journals was $23.42 \pm 19.90$ (range: 79.26-2.12) (according to Clarivate Analytics, 2017). The "Quartile Score" category was Q1 for all the journals (according to SCImago Journal and Country Rank, 2019). Most of the articles were published in NEJM, and NEJM was also the journal with the highest IF. The correlation analysis for the number of citations, ACY, IF and length of time since publication parameters in the $\mathrm{T} 100$ list revealed a positive correlation between citation and ACY $(r=0.744$, $p=0.00)$ and between ACY and IF $(r=0.236, p=0.018)$, whereas a negative correlation was observed between ACY and length of time since publication $(r=-0.562$, $p=0.00)$ and between IF and length of time since publication $(r=-0.266, p=0.008)$. There was no correlation between citation and length of time since publication or between citation and IF (Fig. 1).

According to the geographic origin of the $\mathrm{T} 100$ list, the USA ( $n=74)$ was the most contributing country, followed by Japan and Canada (Table 4). We determined that the most commonly listed institution was the University of Harvard (USA), which was listed 27 times in the top 100 cited articles (Table 5). Moreover, 11/19 of the institutions that published eight or more publications were found to be in USA.

It was seen that 3 authors were the first author in more than one article in the T100 list's top 12 authors (Table 6). Herbst RS contributed to 8 articles and was the first author in 4 of them. Janne PA, Johnson BE and Johnson DH 
Table 4. Geographic origin of the top 100 articles

\begin{tabular}{lc|}
\hline Country & Number of articles \\
United States of America & 74 \\
Japan & 20 \\
Canada & 19 \\
Germany & 19 \\
Italy & 19 \\
England & 18 \\
\hline Spain & 18 \\
\hline France & 18 \\
\hline Netherlands & 10 \\
\hline South Korea & 10 \\
\hline Poland & 9 \\
Australia & 9 \\
Brazil & 8 \\
China & 7 \\
Switzerland & 6 \\
Belgium & 5 \\
Chile & 5 \\
Russia & 5 \\
Taiwan & 5 \\
Denmark & 4 \\
\hline
\end{tabular}

Table 6. The most common authors with 6 or more in the top 100 cited articles

\begin{tabular}{lccc}
\hline \multirow{2}{*}{ Author } & \multicolumn{3}{c}{ Number of top $\mathbf{1 0 0}$ articles } \\
\cline { 2 - 4 } & Author & First author & Co-author \\
Herbst RS & 8 & 4 & 4 \\
Janne PA & 8 & 1 & 7 \\
Johnson BE & 8 & - & 8 \\
Johnson DH & 8 & 1 & 7 \\
Lynch TJ & 7 & 1 & 6 \\
Rosell R & 7 & 3 & 4 \\
Takahashi T & 7 & 1 & 6 \\
Von Pawel J & 7 & - & 7 \\
Felip E & 6 & - & 6 \\
Meyerson M & 6 & - & 6 \\
Settleman J & 6 & - & 6 \\
Shepherd FA & 6 & 2 & 4
\end{tabular}

also contributed to 8 articles. However, Herbst RS had the highest number of articles as first author. The "Web of Science" category analysis of the T100 in the field of the lung cancer revealed that these articles ranked under general internal medicine $(n=47)$, oncology $(n=33)$, multidisciplinary sciences $(n=13)$, cell biology $(n=8)$ and respiratory system $(n=6)$ as the most featured branches.

\section{Discussion}

Lung cancer is the major cause of cancer-related deaths worldwide. There are two main types of this cancer: small-
Table 5. Institutions of origin with 8 or more of the top 100 cited articles

\begin{tabular}{|c|c|c|}
\hline Rank & Institution & Number ${ }^{*}$ \\
\hline 1 & Harvard University & 27 \\
\hline 2 & VA Boston Healthcare System & 26 \\
\hline 3 & Dana Farber Cancer Institute & 17 \\
\hline 4 & University of Texas System & 17 \\
\hline 5 & Memorial Sloan Kettering Cancer Center & 16 \\
\hline 6 & University of California System & 16 \\
\hline 7 & UT MD Anderson Cancer Center & 16 \\
\hline 8 & Massachusetts General Hospital & 15 \\
\hline 9 & Unicancer & 15 \\
\hline 10 & Vanderbilt University & 15 \\
\hline 11 & University of Toronto & 10 \\
\hline 12 & Princess Margaret Cancer Centre & 9 \\
\hline 13 & Ruprecht Karls University Heidelberg & 9 \\
\hline 14 & University Health Network Toronto & 9 \\
\hline 15 & Astrazeneca & 8 \\
\hline 16 & Gustave Roussy & 8 \\
\hline 17 & National Institutes of Health NIH USA & 8 \\
\hline 18 & Samsung Medical Center & 8 \\
\hline 19 & Sungkyunkwan University & 8 \\
\hline 20 & University of California Los Angeles & 8 \\
\hline
\end{tabular}

cell lung cancer (SCLC) and non-small cell lung cancer (NSCLC). NSCLC accounts for $80 \%$ of all lung cancers. Despite the advances in surgical methods and advances in radiotherapy and chemotherapy, non-small-cell lung cancer continues to account for the majority of lung cancers and is associated with a 5-year survival rate of 15\% [112].

There have been significant advances in the treatment of lung cancer in the last 40 years, and this is reflected in the scientific literature. A better understanding of disease progression coupled with targeted immunological therapies has led to increased survival rates.

We found that in our top 100, 28\% of the articles were less than 10 years old while $72 \%$ of them were older than 10 years. Articles with a higher number of citations are indeed expected to be older. Year of publication and number of citations for an article are closely linked, and the number of citations grows over time. Needless to say, citation is an important metric, which shows the quality and attractiveness of an article; however, a certain amount of time should be allowed to pass after the publication of an article for it to reach a higher number of citations. For that reason, number of citations alone is inadequate to determine the quality of an article. In this study, ACY was used to eliminate the time bias when evaluating older articles against newer articles. Of the T100, 18\% were comparative studies, and there were 2 case reports in the T100 list. The two case reports were published in 2005. One of them was published in NEJM (times cited: 2549), and the other in Plos Med (times cited: 2073). Both were about EGFR mutations. It is noteworthy that a case report receives such 
a high number of citations. This may be due to the fact that EGFR mutations were popular in the 2000s. In the T100, $29 \%$ of the articles were noted to concern erlotinib (anti-EGFR), gefitinib (anti-EGFR) and EGFR mutations. The $1^{\text {st }}$ study with the highest number of citations was a study related to EGFR mutations, showing that EGFR mutations play an important role in the development stages of lung cancer treatments.

Immunotherapy has become one of the most promising treatments for several human cancers. In fact, James P. Allison and Tasuku Honjo were awarded with the Nobel Prize in medicine for their research on immune checkpoint blockade $[113,114]$. As a result, the immune check-point inhibitor (ICPI) may be regarded as an immunotherapy modality that started a new era in cancer treatment and remains a new trend topic. Especially in advanced nonsmall cell lung cancer (NSCLC), significant improvement has been observed in survival results with anti-PD-1 and PDL-1 drugs compared to chemotherapy. That shows the changing trends in cancer immunotherapy during the last decade. We can also see studies on immunotherapy in the T100 list. The most cited immunotherapy-related study in T100 was published in 2015 and received 2966 citations (ACY 593.2). It was published in N Engl J Med 2015; 373: 123-135 by Brahmer et al. with the following title: "Nivolumab versus docetaxel in advanced squamouscell non-smallcell lung cancer". This study currently remains a new study of only 4 years old, and despite being a very young article, the number of citations it has received shows that the study in question involves a very important innovation. Moreover, this article has the highest ACY score in the T100 list. This shows that scientists are currently focused on immunotherapy. There are only 7 studies about immunotherapy in the T100, and the newest article in the T100 was published in Lancet 2017; 389: 255-265 by Rittmeyer, titled "Atezolizumab versus docetaxel in patients with previously treated non-smallcell lung cancer (OAK): a phase 3, open-label, multicentre randomised controlled trial". It is only a 2-year-old article; however, it has 926 citations with an ACY score of 308.67. When we list the articles based on ACY scores in descending order, the first 4 articles are immunotherapy-related and recent articles.

The correlation analysis showed a positive correlation between citation and ACY and between ACY and IF whereas a negative correlation was found between ACY and length of time since publication and between IF and length of time since publication. This indicates that articles with high ACY scores have been published in journals with a high IF. Furthermore, younger articles have higher ACY scores and have been published in journals with a higher IF.

When we looked at the T100 list, another point of interest also caught our attention: there were very few articles related to small-cell lung cancer (SCLC). Only 3 articles were on small-cell lung cancer [115-117]. This either means that there has not been any significant advance in SCLC or scientists are less interested in this topic.

\section{Conclusions}

To the best of our knowledge, this is the first report of a citation analysis of lung cancer in the English literature. The first 100 articles in our analysis not only identify landmark articles that have the greatest impact on lung cancer research, but also acknowledge the most productive authors and institutions that contributed to the list with their articles. Oncology is a developing field in science, and we have seen its evolution through the treatment of lung cancer over the years. Briefly, bibliometric analyses for different medical disciplines and sub-specialties demonstrate the improvements in a given field from a nominative perspective. The present bibliometric citation analysis on lung cancer has covered several scientific fields, and we believe it enables the systematic identification of true landmark publications as well as the distribution of citations of these publications by year, main topic, institution, scientific journal, level of evidence, and correlation analysis, thereby providing a substantial contribution for oncological research.

The authors declare no conflict of interest.

\section{References}

1. Cheng TY, Cramb SM, Baade PD, Baade PD, Youlden DR, Nwogu C, Reid ME. The International Epidemiology of Lung Cancer: Latest Trends, Disparities, and Tumor Characteristics. J Thorac Oncol 2016; 11: 1653-1671.

2. Siegel RL, Miller KD, Jemal A. Cancer statistics, 2019. CA Cancer J Clin 2019; 69: 7-34.

3. Kanthala S, Pallerla S, Jois S. Current and future targeted therapies for non-small-cell lung cancers with aberrant EGF receptors. Future Oncol 2015; 11: 865-878.

4. Paladugu R, Schein M, Gardezi S, Wise L. One hundred citation classics in general surgical journals. World J Surg 2002; 26: 10991105.

5. Baltussen A, Kindler $\mathrm{CH}$. Citation classics in anesthetic journals. Anesth Analg 2004; 98: 443-451.

6. Kelly JC, Glynn RW, O'Briain DE, Felle P, McCabe JP. The 100 classic papers of orthopaedic surgery: a bibliometric analysis. J Bone Joint Surg Br 2010; 92: 1338-1343.

7. Fenton JE, Roy D, Hughes JP, Jones AS. A century of citation classics in otolaryngology-head and neck surgery journals. J Laryngol Otol 2002; 116: 494-498.

8. Yoon DY, Yun EJ, Ku YJ, Baek S, Lim KJ, Seo YL, Yie M. Citation classics in radiology journals: the 100 top-cited articles, 1945-2012. AJR Am J Roentgenol 2013; 201: 471-481.

9. Loonen MP, Hage JJ, Kon M. Value of citation numbers and impact factors for analysis of plastic surgery research. Plast Reconstr Surg 2007; 120: 2082.

10. Garfield E. 100 citation classics from the Journal of the American Medical Association. JAMA 1987; 257: 52-59.

11. Scottish Intercollegiate Guidelines Network. SIGN 50: A guideline developer's handbook. November 2011. Available from https:// www.sign.ac.uk/assets/sign50_2011.pdf

12. Lynch TJ, Bell D, Sordella R, et al. Activating mutations in the epidermal growth factor receptor underlying responsiveness of nonsmallcell lung cancer to gefitinib. N Engl J Med 2004; 350: 2129-2139.

13. Aaronson NK, Ahmedzai S, Bergman B, et al. The European Organization for Research and Treatment of Cancer QLQC30: a quality-of-life instrument for use in international clinical trials in oncology. J Natl Cancer Inst 1993; 85: 365-376. 
14. Paez JG, Jänne PA, Lee JC, et al. EGFR mutations in lung cancer: cor relation with clinical response to gefitinib therapy. Science 2004; 304: 1497-1500.

15. Mok TS, Wu YL, Thongprasert S, et al. Gefitinib or carboplatin-paclitaxel in pulmonary adenocarcinoma. N Engl J Med 2009; 361 947-957.

16. Shepherd FA, Rodrigues Pereira J, Ciuleanu T, et al. Erlotinib in previously treated nonsmallcell lung cancer. N Engl J Med 2005; 353 123-132.

17. Sandler A, Gray R, Perry MC, et al. Paclitaxel-carboplatin alone or with bevacizumab for non-small-cell lung cancer. N Engl J Med 2006; 355: 2542-2550.

18. Schiller JH, Harrington D, Belani CP, et al. Comparison of four chemotherapy regimens for advanced non-small-cell lung cancer. N Engl J Med 2002; 346: 92-98.

19. Mountain CF. Revisions in the International System for Staging Lung Cancer. Chest 1997; 111: 1710-1717.

20. National Lung Screening Trial Research Team, Aberle DR, Adams AM, et al. Reduced lung-cancer mortality with lowdose computed tomographic screening. N Engl J Med 2011; 365: 395-409.

21. Maemondo M, Inoue A, Kobayashi K, et al. Gefitinib or chemotherapy for non-small-cell lung cancer with mutated EGFR. N Engl J Med. 2010; 362: 2380-2388.

22. Temel JS, Greer JA, Muzikansky A, et al. Early palliative care for patients with metastatic non-small-cell lung cancer. N Engl J Med 2010; 363: 733-742

23. Engelman JA, Zejnullahu K, Mitsudomi T, et al. MET amplification leads to gefitinib resistance in lung cancer by activating ERBB3 signaling. Science 2007; 316: 1039-1043.

24. Brahmer J, Reckamp KL, Baas P, et al. Nivolumab versus Docetaxel in Advanced Squamous-Cell Non-Small-Cell Lung Cancer. N Engl J Med 2015; 373: 123-135.

25. Soda M, Choi YL, Enomoto M, et al. Identification of the transforming EML4-ALK fusion gene in non-small-cell lung cancer. Nature 2007; 448: 561-566.

26. Kwak EL, Bang YJ, Camidge DR, et al. Anaplastic lymphoma kinase inhibition in non-small-cell lung cancer. N Engl J Med 2010; 363: 1693-1703.

27. Borghaei H, Paz-Ares L, Horn L, et al. Nivolumab versus Docetaxel in Advanced Nonsquamous Non-Small-Cell Lung Cancer. Engl J Med 2015; 373: 1627-1639.

28. Rosell R, Carcereny E, Gervais R, et al. Erlotinib versus standard chemotherapy as first-line treatment for European patients with advanced EGFR mutation-positive non-small-cell lung cancer (EURTAC): a multicentre, open-label, randomised phase 3 trial. Lancet Oncol 2012; 13: 239-246.

29. Cole SP, Bhardwaj G, Gerlach JH, et al. Overexpression of a trans porter gene in a multidrug-resistant human lung cancer cell line. Science 1992; 258: 1650-1654.

30. Kobayashi S, Boggon TJ, Dayaram T, et al. EGFR mutation and resistance of non-small-cell lung cancer to gefitinib. N Engl J Med 2005; 352: 786-792.

31. Rizvi NA, Hellmann MD, Snyder A, et al. Cancer immunology. Mutational landscape determines sensitivity to PD-1 blockade in nonsmall cell lung cancer. Science 2015; 348: 124-128.

32. Non-small Cell Lung Cancer Collaborative Group. Chemotherapy in non-small cell lung cancer: a meta-analysis using updated data on individual patients from 52 randomised clinical trials. BMJ 1995 . 311: 899-909.

33. Mitsudomi T, Morita S, Yatabe Y, et al. Gefitinib versus cisplatin plus docetaxel in patients with non-small-cell lung cancer harbouring mutations of the epidermal growth factor receptor (WJTOG3405): an open label, randomised phase 3 trial. Lancet Oncol 2010; 11: 121-128.

34. Travis WD, Brambilla E, Noguchi M, et al. International association for the study of lung cancer/american thoracic society/european respiratory society international multidisciplinary classification of lung adenocarcinoma. J Thorac Oncol 2011; 6: 244-285.

35. Fukuoka M, Yano S, Giaccone G, et al. Multi-institutional random ized phase II trial of gefitinib for previously treated patients with advanced non-small-cell lung cancer (The IDEAL 1 Trial). J Clin Oncol 2003; 21: 2237-2246.
36. Zhou C, Wu YL, Chen G, et al. Erlotinib versus chemotherapy as firstline treatment for patients with advanced EGFR mutation-positive non-small-cell lung cancer (OPTIMAL, CTONG0802): a multicentre, open-label, randomised, phase 3 study. Lancet Oncol 2011; 12: 735-742.

37. Yanaihara N, Caplen N, Bowman E, et al. Unique microRNA molecular profiles in lung cancer diagnosis and prognosis. Cancer Cell 2006; 9: 189-198.

38. Goldstraw P, Crowley J, Chansky K, et al. The IASLC Lung Cancer Staging Project: proposals for the revision of the TNM stage groupings in the forthcoming (seventh) edition of the TNM Classification of malignant tumours. J Thorac Oncol 2007; 2: 706-714.

39. Garon EB, Rizvi NA, Hui R, et al. Pembrolizumab for the treatment of non-small-cell lung cancer. N Engl J Med 2015; 372: 2018-2028.

40. Scagliotti GV, Parikh P, von Pawel J, et al. Phase III study comparing cisplatin plus gemcitabine with cisplatin plus pemetrexed in chemotherapy-naive patients with advanced-stage non-small-cell lung cancer. J Clin Oncol 2008; 26: 3543-3551.

41. Pao W, Miller VA, Politi KA, et al. Acquired resistance of lung adenocarcinomas to gefitinib or erlotinib is associated with a second mutation in the EGFR kinase domain. PLoS Med 2005; 2: e73.

42. Kris MG, Natale RB, Herbst RS, et al. Efficacy of gefitinib, an inhibitor of the epidermal growth factor receptor tyrosine kinase, in symptomatic patients with non-small cell lung cancer: a randomized trial. JAMA 2003; 290: 2149-2158.

43. Reck M, Rodríguez-Abreu D, Robinson AG, et al. Pembrolizumab versus Chemotherapy for PD-L1-Positive Non-Small-Cell Lung Cancer. N Engl J Med 2016; 375: 1823-1833.

44. Shaw AT, Kim DW, Nakagawa K, et al. Crizotinib versus chemotherapy in advanced ALK-positive lung cancer. N Engl J Med 2013; 368: 2385-2394.

45. Cancer Genome Atlas Research Network. Comprehensive genomic characterization of squamous cell lung cancers. Nature 2012; 489: 519-525.

46. Hanna N, Shepherd FA, Fossella FV, et al. Randomized phase III trial of pemetrexed versus docetaxel in patients with non-smallcell lung cancer previously treated with chemotherapy. J Clin Oncol 2004; 22: 1589-1597.

47. Takamizawa J, Konishi H, Yanagisawa K, et al. Reduced expression of the let-7 microRNAs in human lung cancers in association with shortened postoperative survival. Cancer Res 2004; 64: 3753-3756.

48. Sharma SV, Bell DW, Settleman J, Haber DA. Epidermal growth factor receptor mutations in lung cancer. Nat Rev Cancer 2007; 7: 169-181.

49. Herbst RS, Baas P, Kim DW, et al. Pembrolizumab versus docetaxe for previously treated, PD-L1- positive, advanced non-small-cell lung cancer (KEYNOTE-010): a randomised controlled trial. Lancet 2016; 387: 1540-1550.

50. Henschke Cl, McCauley DI, Yankelevitz DF, et al. Early Lung Cancer Action Project: overall design and findings from baseline screening. Lancet 1999; 354: 99-105.

51. Bhattacharjee A, Richards WG, Staunton J, et al. Classification of human lung carcinomas by mRNA expression profiling reveals distinct adenocarcinoma subclasses. Proc Natl Acad Sci U S A 2001; 98: 13790-13795.

52. Sequist LV, Waltman BA, Dias-Santagata D, et al. Genotypic and histological evolution of lung cancers acquiring resistance to EGFR inhibitors. Sci Transl Med 2011; 3: 75ra26.

53. Thatcher N, Chang A, Parikh P, et al. Gefitinib plus best supportive care in previously treated patients with refractory advanced nonsmall-cell lung cancer: results from a randomised, placebo-controlled, multicentre study (Iressa Survival Evaluation in Lung Cancer). Lancet 2005; 366: 1527-1537.

54. Shigematsu H, Lin L, Takahashi T, et al. Clinical and biological features associated with epidermal growth factor receptor gene mutations in lung cancers. J Natl Cancer Inst 2005; 97: 339-346.

55. Shepherd FA, Dancey J, Ramlau R, et al. Prospective randomized trial of docetaxel versus best supportive care in patients with nonsmall-cell lung cancer previously treated with platinum-based chemotherapy. J Clin Oncol 2000; 18: 2095-2103. 
56. Murren JR, Buzaid AC, Hait WN. Critical analysis of neoadjuvant therapy for Stage IIIa non-small cell lung cancer. Am Rev Respir Dis 1991; 143: 889-894.

57. Mountain CF. A new international staging system for lung cancer. Chest 1986; 89: 225S-233S.

58. Rosell R, Moran T, Queralt C, et al. Screening for epidermal growth factor receptor mutations in lung cancer. N Engl J Med 2009; 361: 958-967.

59. Arriagada R, Bergman B, Dunant A, Le Chevalier T, Pignon JP, Vansteenkiste J; International Adjuvant Lung Cancer Trial Collaborative Group. Cisplatin-based adjuvant chemotherapy in patients with completely resected non-small-cell lung cancer. N Engl J Med 2004; 350: 351-360.

60. Herbst RS, Heymach JV, Lippman SM. Lung cancer. N Engl J Med 2008; 359: 1367-1380.

61. Rikova K, Guo A, Zeng Q, et al. Global survey of phosphotyrosine signaling identifies oncogenic kinases in lung cancer. Cell 2007; 131: 1190-1203.

62. Johnson DH, Fehrenbacher L, Novotny WF, et al. Randomized phase II trial comparing bevacizumab plus carboplatin and paclitaxel with carboplatin and paclitaxel alone in previously untreated locally advanced or metastatic non-small-cell lung cancer. J Clin Oncol 2004; 22: 2184-2191.

63. Tsao MS, Sakurada A, Cutz JC, et al. Erlotinib in lung cancer - molecular and clinical predictors of outcome. N Engl J Med 2005; 353 : 133-144.

64. Kim CF, Jackson EL, Woolfenden AE, et al. Identification of bronchioalveolar stem cells in normal lung and lung cancer. Cell 2005; 121: 823-835.

65. Timmerman R, Paulus R, Galvin J, et al. Stereotactic body radiation therapy for inoperable early stage lung cancer. JAMA 2010; 303: 1070-1076.

66. Giaccone G, Herbst RS, Manegold C, et al. Gefitinib in combination with gemcitabine and cisplatin in advanced non-small-cell lung cancer: a phase III trial - INTACT 1. J Clin Oncol 2004; 22: 777-784.

67. Herbst RS, Giaccone G, Schiller JH, et al. Gefitinib in combination with paclitaxel and carboplatin in advanced non-small-cell lung cancer: a phase III trial - INTACT 2. J Clin Oncol 2004; 22: 785-794.

68. Solomon BJ, Mok T, Kim DW, et al. First-line crizotinib versus chemotherapy in ALK-positive lung cancer. N Engl J Med 2014; 371: 2167-2177.

69. Denissenko MF, Pao A, Tang M, Pfeifer GP. Preferential formation of benzo[a]pyrene adducts at lung cancer mutational hotspots in P53. Science 1996 ; 274: 430-432.

70. Olaussen KA, Dunant A, Fouret P, et al. DNA repair by ERCC1 in nonsmall-cell lung cancer and cisplatinbased adjuvant chemotherapy. N Engl J Med 2006; 355: 983-991.

71. Hecht SS. Tobacco smoke carcinogens and lung cancer. J Natl Cancer Inst 1999; 91: 1194-1210.

72. Molina JR, Yang P, Cassivi SD, Schild SE, Adjei AA. Non-small cell lung cancer: epidemiology, risk factors, treatment, and survivor ship. Mayo Clin Proc 2008; 83: 584-594.

73. Cuttitta F, Carney DN, Mulshine J, et al. Bombesin-like peptides can function as autocrine growth factors in human small-cell lung cancer. Nature 1985; 316: 823-826.

74. Cappuzzo F, Hirsch FR, Rossi E, et al. Epidermal growth factor receptor gene and protein and gefitinib sensitivity in non-small-cell lung cancer. J Natl Cancer Inst 2005; 97: 643-655.

75. Sordella R, Bell DW, Haber DA, Settleman J. Gefitinib-sensitizing EGFR mutations in lung cancer activate antiapoptotic pathways. Science 2004; 305: 1163-1167.

76. Winton T, Livingston R, Johnson D, et al. Vinorelbine plus cisplatin vs. observation in resected non-small-cell lung cancer. N Engl J Med 2005; 352: 2589-2597.

77. Takahashi T, Nau MM, Chiba I, et al. p53: a frequent target for ge netic abnormalities in lung cancer. Science 1989; 246: 491-494.

78. Maheswaran S, Sequist LV, Nagrath S, et al. Detection of mutations in EGFR in circulating lung-cancer cells. N Engl J Med 2008; 359: 366-377.

79. Iggo R, Gatter K, Bartek J, Lane D, Harris AL. Increased expression of mutant forms of p53 oncogene in primary lung cancer. Lancet 1990; 335: 675-679.
80. Ji P, Diederichs S, Wang W, et al. MALAT-1, a novel noncoding RNA, and thymosin beta4 predict metastasis and survival in early-stage non-small cell lung cancer. Oncogene 2003; 22: 8031-8041.

81. Shaw AT, Yeap BY, Mino-Kenudson M, et al. Clinical features and outcome of patients with non-small-cell lung cancer who harbor EML4-ALK. J Clin Oncol 2009; 27: 4247-4253.

82. Crawford J, Ozer H, Stoller R, et al. Reduction by granulocyte colony-stimulating factor of fever and neutropenia induced by chemotherapy in patients with small-cell lung cancer. N Engl J Med 1991; 325: 164-170.

83. Hayashita Y, Osada H, Tatematsu Y, et al. A polycistronic microRNA cluster, miR-17-92, is overexpressed in human lung cancers and enhances cell proliferation. Cancer Res 2005; 65: 9628-9632.

84. Herbst RS, Prager D, Hermann R, et al. TRIBUTE: a phase III trial of erlotinib hydrochloride (OSI-774) combined with carboplatin and paclitaxel chemotherapy in advanced non-small-cell lung cancer. J Clin Oncol 2005; 23: 5892-5899.

85. Eberhard DA, Johnson BE, Amler LC, et al. Mutations in the epidermal growth factor receptor and in KRAS are predictive and prognostic indicators in patients with non-small-cell lung cancer treated with chemotherapy alone and in combination with erlotinib. J Clin Oncol 2005; 23: 5900-5909.

86. Eramo A, Lotti F, Sette G, et al. Identification and expansion of the tumorigenic lung cancer stem cell population. Cell Death Differ 2008; 15: 504-514.

87. Fabbri M, Garzon R, Cimmino A, et al. MicroRNA-29 family reverts aberrant methylation in lung cancer by targeting DNA methyltransferases 3A and 3B. Proc Natl Acad Sci U S A 2007; 104: 1580515810.

88. Yun CH, Mengwasser KE, Toms AV, et al. The T790M mutation in EGFR kinase causes drug resistance by increasing the affinity for ATP. Proc Natl Acad Sci U S A 2008; 105: 2070-2075.

89. Schaake-Koning C, van den Bogaert W, Dalesio O, et al. Effects of concomitant cisplatin and radiotherapy on inoperable non-smallcell lung cancer. N Engl J Med 1992; 326: 524-530.

90. Furuse K, Fukuoka M, Kawahara M, et al. Phase III study of concurrent versus sequential thoracic radiotherapy in combination with mitomycin, vindesine, and cisplatin in unresectable stage III nonsmall-cell lung cancer. J Clin Oncol 1999; 17: 2692-2699.

91. International Early Lung Cancer Action Program Investigators, Henschke CI, Yankelevitz DF, Libby DM, et al. Survival of patients with stage I lung cancer detected on CT screening. N Engl J Med 2006; 355: 1763-1771.

92. Pignon JP, Tribodet H, Scagliotti GV, et al. Lung adjuvant cisplatin evaluation: a pooled analysis by the LACE Collaborative Group. I Clin Oncol 2008; 26: 3552-3559.

93. Reck M, von Pawel J, Zatloukal P, et al. Phase III trial of cisplatin plus gemcitabine with either placebo or bevacizumab as first-line therapy for nonsquamous non-small-cell lung cancer: AVAil. J Clin Oncol 2009; 27: 1227-1234.

94. Jackson EL, Willis N, Mercer K, et al. Analysis of lung tumor initiation and progression using conditional expression of oncogenic K-ras. Genes Dev 2001; 15: 3243-3248.

95. Pirker R, Pereira JR, Szczesna A, et al. Cetuximab plus chemotherapy in patients with advanced nonsmall-cell lung cancer (FLEX): an open-label randomised phase III trial. Lancet 2009; 373: 1525-1531.

96. Kim ES, Hirsh V, Mok T, et al. Gefitinib versus docetaxel in previously treated non-small-cell lung cancer (INTEREST): a randomised phase III trial. Lancet 2008; 372: 1809-1818.

97. Govindan R, Page N, Morgensztern D, et al. Changing epidemiology of small-cell lung cancer in the United States over the last 30 years: analysis of the surveillance, epidemiologic, and end results database. J Clin Oncol 2006; 24: 4539-4544.

98. Jänne PA, Yang JC, Kim DW, et al. AZD9291 in EGFR inhibitor-resistant non-small-cell lung cancer. N Engl J Med 2015; 372: 1689-1699.

99. Fossella FV, DeVore R, Kerr RN, et al. Randomized phase III trial of docetaxel versus vinorelbine or ifosfamide in patients with advanced non-small-cell lung cancer previously treated with platinum-containing chemotherapy regimens. The TAX 320 Non-Small Cell Lung Cancer Study Group. J Clin Oncol 2000; 18: 2354-2362. 
100.Pfister DG, Johnson DH, Azzoli CG, et al. American Society of Clinical Oncology treatment of unresectable non-small-cell lung cancer guideline: update 2003. J Clin Oncol 2004; 22: 330-353.

101. Lardinois D, Weder W, Hany TF, et al. Staging of non-small-cell lung cancer with integrated positronemission tomography and computed tomography. N Engl J Med 2003; 348: 2500-2507.

102. Dillman RO, Seagren SL, Propert KJ, et al. A randomized trial of induction chemotherapy plus high-dose radiation versus radiation alone in stage III non-small-cell lung cancer. N Engl J Med 1990; 323: 940-945.

103. Mountain CF, Dresler CM. Regional lymph node classification for lung cancer staging. Chest 1997; 111: 1718-1723.

104. Aupérin A, Arriagada R, Pignon JP, et al. Prophylactic cranial irradiation for patients with small-cell lung cancer in complete re mission. Prophylactic Cranial Irradiation Overview Collaborative Group. N Engl J Med 1999; 341: 476-484.

105. Rosell R, Gómez-Codina J, Camps C, et al. A randomized trial comparing preoperative chemotherapy plus surgery with surgery alone in patients with non-small-cell lung cancer. N Engl J Med 1994; 330: 153-158.

106. Rittmeyer A, Barlesi F, Waterkamp D, et al. Atezolizumab versus docetaxel in patients with previously treated non-small-cell lung cancer (OAK): a phase 3, open-label, multicentre randomised controlled trial. Lancet 2017; 389: 255-265.

107. Douillard JY, Rosell R, De Lena M, et al. Adjuvant vinorelbine plus cisplatin versus observation in patients with completely resected stage IB-IIIA non-small-cell lung cancer (Adjuvant Navelbine International Trialist Association [ANITA]): a randomised controlled trial. Lancet Oncol 2006; 7: 719-727.

108. Kosaka T, Yatabe Y, Endoh H, Kuwano H, Takahashi T, Mitsudomi T. Mutations of the epidermal growth factor receptor gene in lung cancer: biological and clinical implications. Cancer Res 2004; 64: 8919-8923.

109. Cappuzzo F, Ciuleanu T, Stelmakh L, et al. Erlotinib as maintenance treatment in advanced non-small-cell lung cancer: a multicentre, randomised, placebo-controlled phase 3 study. Lancet Oncol 2010; 11: 521-529.

110. Pignon JP, Arriagada R, Ihde DC, et al. A meta-analysis of thoracic radiotherapy for small-cell lung cancer. N Engl J Med 1992; 327: 1618-1624.

111. Imielinski M, Berger AH, Hammerman PS, et al. Mapping the hallmarks of lung adenocarcinoma with massively parallel sequencing. Cell 2012; 150: 1107-1120.

112. Molina JR, Yang P, Cassivi SD, Schild SE, Adjei AA. Non-small cell lung cancer: epidemiology, risk factors, treatment, and survivorship. Mayo Clin Proc 2008; 83: 584-594.

113. Allison JP. Checkpoints. Cell 2015; 162: 1202-1205.

114. Honjo T. $112^{\text {th }}$ Scientific Meeting of the Japanese Society of Internal Medicine: Special Lecture: Cancer Immunotherapy by PD-1 Antibody. Nihon Naika Gakkai Zasshi 2015; 104: 1917.

115. Crawford J, Ozer H, Stoller R, et al. Reduction by granulocyte colony-stimulating factor of fever and neutropenia induced by che motherapy in patients with small-cell lung cancer. N Engl J Med 1991; 325: 164-170

116. Govindan R, Page N, Morgensztern D et al. Changing epidemiology of small-cell lung cancer in the United States over the last 30 years: analysis of the surveillance, epidemiologic, and end results database. J Clin Oncol 2006; 24: 4539-4544.

117. Pignon JP, Arriagada R, Ihde DC et al. A meta-analysis of thoracic radiotherapy for small-cell lung cancer. N Engl J Med 1992; 327: 1618-1612.

\section{Address for correspondence}

\section{Nilay Sengul Samanci}

Department of Medical Oncology

Istanbul University Cerrahpasa Medical Faculty 34096 Istanbul, Turkey

e-mail: nilaysengulsamanci@gmail.com

Submitted: 12.11 .2019

Accepted: 5.01.2020 